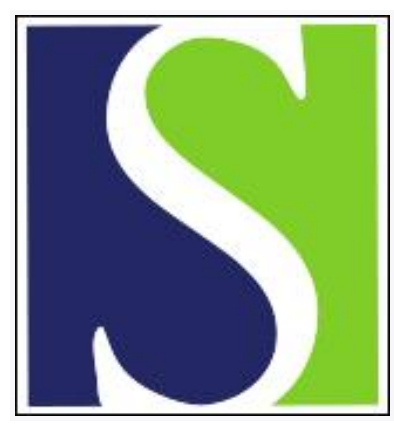

Scand J Work Environ Health 1991;17(4):248-254

https://doi.org/10.5271/sjweh.1706

Issue date: Aug 1991

Occupation and cancer of the oral cavity or oropharynx in Turin, Italy.

by Merletti F, Boffetta P, Ferro G, Pisani P, Terracini B

Affiliation: Unit of Cancer Epidemiology, University of Turin, Italy.

This article in PubMed: www.ncbi.nlm.nih.gov/pubmed/1925436 


\title{
Occupation and cancer of the oral cavity or oropharynx in Turin, Italy
}

\author{
by Franco Merletti, MD, ${ }^{1}$ Paolo Boffetta, MD, ${ }^{1,2}$ Gilles Ferro, BS, ${ }^{2}$ Paola Pisani, DSc, ${ }^{3}$ \\ Benedetto Terracini, MD, ${ }^{1}$
}

\begin{abstract}
MERLETTI F, BOFFETTA P, FERRO G, PISANI P, TERRACINI B. Occupation and cancer of the oral cavity or oropharynx in Turin, Italy. Scand J Work Environ Health 1991;17:248-54. In a population-based case-referent study, the occupational experience of 86 men with oral or oropharyngeal cancer and 373 referents was analyzed with respect to employment in 41 occupations and 40 industries, as well as to exposure to 16 chemicals, as estimated via a job-exposure matrix. Among the occupations and industries at higher risk were machinery operator (odds ratio [OR] 2.0; $95 \%$ confidence interval [95\% CI] 1.0-4.0), plumber (OR 5.0, $95 \%$ CI 1.2-21.5), building industry (OR 2.5; $95 \%$ CI 1.3-4.5), textile industry (OR $2.5 ; 95 \% \mathrm{CI} 0.6-4.6$ ), and electricity production (OR 2.8; $95 \% \mathrm{CI} 0.7-12.1$ ). All the OR estimates were adjusted for age, education, area of birth, tobacco smoking, and alcohol consumption. An association between formaldehyde exposure and oral cancer was suggested (OR for any exposure 1.6, $95 \%$ CI 0.9-2.8; OR for probable or definite exposure $1.8,95 \%$ CI $0.6-5.5$ ). No other chemical included in the matrix showed any risk pattern. The evidence of an association between formaldehyde exposure and oral or oropharyngeal cancer is strengthened by the results of this study.
\end{abstract}

Key terms: asbestos, formaldehyde, job-exposure matrices.

\begin{abstract}
Alcohol consumption and tobacco smoking are established risk factors for oral and oropharyngeal cancers $(1,2)$, and their etiologic role has recently been confirmed in a study carried out in the city of Turin, Italy (3). However, other environmental factors, such as diet and occupation, have been suggested to play an etiologic role (4). This paper reports the results of the analysis of occupational risk factors in the Turin study.
\end{abstract}

\section{Subjects and methods}

This was a population-based case-referent study and included all incident cases of oral or oropharyngeal cancers diagnosed between 1 July 1982 and 31 December 1984 among residents of the city of Turin. The referents were a random sample stratified by gender and age from the files of residents of the city of Turin; they were interviewed between 1980 and 1984 when a case-referent study of cancer of the larynx, described in detail elsewhere, was under way $(5,6)$. Only men were included in this analysis.

Throughout the period covered by the study, there were 103 eligible cases, corresponding to annual incidence rates (age standardized on the world population)

${ }^{1}$ Unit of Cancer Epidemiology, University of Turin, Turin, Italy.

2 Unit of Analytical Epidemiology, International Agency for Research on Cancer, Lyon, France.

3 Unit of Epidemiology, National Cancer Institute, Milan, Italy.

Reprint requests to: Dr F Merletti, Epidemiologia dei Tumori, Dipartimento di Scienze Biomediche e Oncologia Umana, Università di Torino, Via Santena 7, I-10126, Turin, Italy. of $5.76 \times 10^{-5}$. Eighty-six of the men were interviewed. Of the noninterviewed men, five refused, two were not traced, and ten were deceased or too sick to undertake a satisfactory interview. Oropharynx, oral tongue, floor of the mouth, soft palate complex, other sites, and unspecified sites of the oral cavity comprised $12,15,24,14,11$, and 10 cases, respectively.

The participation of referents was less satisfactory. Only 385 of 679 men $(56.7 \%)$ were interviewed. The referents who were younger and more educated were more likely to respond, while no difference was suggested according to area of birth. The response rate of eligible cases and referents by age, education, and area of birth is given elsewhere (3). Only 373 referents with a full occupational history and age within the age range of that of the cases (26-92 years) were retained in this analysis. Twenty-six cases were $\leq 55$ years of age, 34 were 55-64 years of age, and 26 were $\geq 65$ years of age. The corresponding numbers of referents for the three age classes were 127,119 , and 127 , respectively.

The cases and referents were personally interviewed by one of eight trained interviewers using the same questionnaire. There were no changes in the interview process, interviewers, or questionnaire over the period of study. Lifelong smoking and drinking histories and a detailed description of the occupational history, current diet, and any major change in diet in the past were collected (5). The interviewers were not blinded as to the case-referent status, and the distribution of the cases and referents interviewed by each of them was not homogeneous. However no major differences were found among the interviewers with respect to number 
of changes in smoking habits and jobs in the occupational histories.

The occupational history was recorded starting from 1945. For each job lasting at least six months, information on job title, activity of the plant, and type of production was collected. The mean number of recorded jobs was 2.7 for the cases and 2.5 for the referents. Blind coding of the occupational histories was performed by trained investigators. Job titles and economic activities were coded according to the International Standard Classification of Occupations of the International Labour Office (ILO), revised edition 1968 (7), and to the four-digit International Standard Industrial Classification (ISIC) of all economic activities (hereafter defined as industries) of the United Nations (8). Ten percent of the questionnaires were double checked for coding accuracy. Coding errors amounted to less than $3 \%$. A total of 771 distinct ILOISIC code combinations, out of a total number of 1150 jobs, were allocated. For each occupational category and each industry the subjects were classified as ever versus never employed (ie, exposed). For each subgroup of production (ie, manufacturing workers: ILO major groups $7 / 8 / 9$ ) the analysis was repeated with only the subjects in other production subgroups classified as unexposed. Duration was calculated for each period of employment, and the exposed workers were classified into two levels according to the distribution of the referents. A latency analysis was also carried out in which occupational history after 1967 was ignored

A job-exposure matrix for 13 agents which are or may be related to respiratory cancer (9) (asbestos, polycyclic aromatic hydrocarbons, chromium and compounds, nickel and compounds, arsenic and compounds, man-made mineral fibers, wood dust, leather dust, isopropyl alcohol, diethyl sulfate, naphthalene, sulfuric acid, formaldehyde) and three nonspecific exposures (dust, gas, and solvents) was applied to this data base. This matrix had been developed for a collaborative study on larynx cancer by the International Agency for Research on Cancer (10). Each ILO-ISIC combination was assessed with regard to probability and intensity of exposure to the 16 agents in three different periods, 1945-1955, 1956-1965, and 1966 onwards, by a panel of two industrial hygienists and three physicians with experience in occupational health and epidemiology. The exposures were grouped into the following five categories: (i) job-related exposure not higher than that of the general population; (ii) possible cumulative exposure (job-related) higher than that of the general population; (iii) possible job-related exposure to levels definitely higher than that of the general population, but available information not sufficient to discriminate between exposed and unexposed; (iv) job-related exposure to the specific agent; (v) jobrelated exposure to the specific agent, and exposure known to be particularly high. Category iii was further divided into three subgroups as (a) less than one- third, (b) between one-third and two-thirds, and (c) greater than two-thirds of the workers in the ILO-ISIC combinations likely to be exposed. Quality controls of the job-exposure matrix have been carried out for the consistency of the ILO-ISIC combinations within each of the possible levels of exposure. In the present analysis the reference category for each agent contained subjects with all ILO-ISIC combinations related to exposure not higher than that of the general population. The "any exposure" category contained subjects with at least one ILO-ISIC combination entailing a cumulative exposure possibly or definitely higher than that of the general population (categories $\mathrm{i}-\mathrm{v}$ ), and the "probable or definite exposure" category contained subjects with exposure very probably or definitely higher than that of the general population (categories iii $\mathrm{c}$ to $\mathrm{v}$ ).

The odds ratios and their $95 \%$ confidence interval (95 \% CI) were calculated by unconditional logistic regression (11) with the use of the GLIM (general linear modeling) statistical package (12). The possible confounders taken into account were age $(\leq 54$, $55-64, \geq 65$ years), education ( $\leq 5,6-8, \geq 9$ school years), birth place (northern Italy, southern-central Italy, abroad), tobacco smoking $(0,1-15,16-24, \geq 25$ grams per day during smoking life), and alcohol consumption $(0-20,21-40, \geq 41$ grams per day during drinking life). The same categories of tobacco smoking and alcohol consumption were used in the analysis of effect modification.

\section{Results}

Table 1 gives the absolute numbers of cases and referents and the odds ratio (OR) estimates for the ILO job groups (one- or two-digit codes) and selected job titles including at least two exposed cases and one exposed referent. A significant increase in risk was found for service workers and production workers. A significant reduction in risk was found for sales workers. Among the service workers, working proprietors and cooks, waiters, and bartenders had high OR estimates. When the latter group was further subdivided, there were one case and three referents classified as waiters or bartenders, and two cases and no referent classified as cooks. Among production workers, the following subgroups showed a significantly increased OR: chemical workers, tailors and sewers, machinery fitters and assemblers, and plumbers and pipe fitters. Miners, metal workers, electrical workers, stationary engine operators, and dock workers showed a nonsignificant increase in risk (OR $>1.5$ ), as did textile workers and painters (OR 1.4 and 1.5, respectively). When only subjects employed as production workers were retained in the analysis, the confidence intervals were wider. But only miners showed a substantially lowered OR (OR 1.1), whereas the OR estimates for the remaining groups showed minor changes. 
Table 1. Odds ratio (OR) and $95 \%$ confidence interval $(95 \% \mathrm{Cl})$ for oral cancer by occupational group and selected job titles.

\begin{tabular}{|c|c|c|c|c|}
\hline Occupation ${ }^{a}$ & $\begin{array}{l}\text { Exposed } \\
\text { cases }\end{array}$ & $\begin{array}{l}\text { Exposed } \\
\text { referents }\end{array}$ & $\mathrm{OR}^{\mathrm{b}}$ & $95 \% \mathrm{Cl}$ \\
\hline Professional, technical and related workers $(0 / 1)$ & 13 & 58 & 1.8 & $0.8-4.0$ \\
\hline Administrative and managerial workers (2) & 4 & 25 & 0.9 & $0.3-3.2$ \\
\hline Clerical and related workers $(3)$ & 13 & 90 & 0.7 & $0.3-1.3$ \\
\hline Sales workers (4) & 4 & 70 & 0.2 & $0.1-0.5$ \\
\hline Service workers (5) & 15 & 36 & 2.7 & $1.0-4.6$ \\
\hline $\begin{array}{l}\text { Working proprietors }(5-1) \\
\text { Cooks, waiters, bartenders }(5-3) \\
\text { Building caretakers, charworkers, cleaners }(5-5) \\
\text { Protective service workers }(5-8) \\
\text { Service workers }{ }^{c}(5-9)\end{array}$ & $\begin{array}{l}3 \\
3 \\
3 \\
3 \\
3\end{array}$ & $\begin{array}{r}1 \\
3 \\
7 \\
17 \\
4\end{array}$ & $\begin{array}{r}14.7 \\
10.3 \\
1.7 \\
0.5 \\
5.9\end{array}$ & $\begin{array}{l}1.0-206.5 \\
1.3-81.2 \\
0.4-8.1 \\
0.1-2.0 \\
1.0-35.4\end{array}$ \\
\hline Agricultural, animal husbandry and forestry workers (6) & 13 & 41 & 1.1 & $0.6-2.5$ \\
\hline Production and related workers, transport equipment $(7 / 8 / 9)$ & 69 & 235 & 2.3 & $1.1-5.0$ \\
\hline $\begin{array}{l}\text { Production supervisors and general foremen }(7-0) \\
\text { Miners, quarrymen, well drillers }(7-1) \\
\text { Metal workers }(7-2) \\
\text { Chemical processers and related workers }(7-4) \\
\text { Food and beverage processers }(7-7) \\
\text { Tailors, dressmakers, sewers }(7-9) \\
\text { Cabinetmakers and related woodworkers }(8-1) \\
\text { Blacksmiths, toolmakers and machine-tool operators }(8-3) \\
\text { Machinery fitters and assemblers, precision instrument }\end{array}$ & $\begin{array}{r}4 \\
2 \\
6 \\
4 \\
3 \\
3 \\
5 \\
14\end{array}$ & $\begin{array}{r}25 \\
5 \\
10 \\
2 \\
14 \\
8 \\
13 \\
60\end{array}$ & $\begin{array}{l}0.7 \\
1.9 \\
2.1 \\
8.3 \\
0.7 \\
6.8 \\
1.2 \\
0.8\end{array}$ & $\begin{array}{l}0.2-2.2 \\
0.3-11.4 \\
0.7-6.7 \\
1.3-55.0 \\
0.2-2.5 \\
1.4-33.7 \\
0.4-3.9 \\
0.4-1.7\end{array}$ \\
\hline makers (except electrical) $(8-4)$ & 18 & 43 & 2.0 & $1.0-4.0$ \\
\hline Machinery fitters and assemblers $(8-41,8-49)$ & 15 & 33 & 1.9 & $0.9-4.1$ \\
\hline $\begin{array}{l}\text { Electrical fitters and related electrical and } \\
\text { electronics workers }(8-5)\end{array}$ & 7 & 13 & 1.7 & $0.6-5.0$ \\
\hline $\begin{array}{l}\text { Electrical and electronics fitters and equipment } \\
\text { assemblers }(8-51,8-52,8-53) \\
\text { Electrical wirement }(8-55)\end{array}$ & $\begin{array}{l}4 \\
4\end{array}$ & $\begin{array}{l}9 \\
2\end{array}$ & $\begin{array}{l}1.6 \\
4.1\end{array}$ & $\begin{array}{l}0.4-6.2 \\
0.7-23.7\end{array}$ \\
\hline Plumbers, welders, metal preparers and erectors $(8-7)$ & 11 & 37 & 1.3 & $0.6-2.8$ \\
\hline $\begin{array}{l}\text { Plumbers and pipe fitters }(8-71) \\
\text { Welders and flame-cutters }(8-72)\end{array}$ & $\begin{array}{l}6 \\
5\end{array}$ & $\begin{array}{r}5 \\
18\end{array}$ & $\begin{array}{l}5.0 \\
1.3\end{array}$ & $\begin{array}{l}1.8-21.5 \\
0.4-3.7\end{array}$ \\
\hline $\begin{array}{l}\text { Rubber and plastics product makers }(9-0) \\
\text { Printers and related workers }(9-2) \\
\text { Painters }(9-3) \\
\text { Bricklayers, carpenters and other construction workers }(9-5) \\
\text { Stationary engine and related equipment operators }(9-6) \\
\text { Material-handling and related equipment operators, }\end{array}$ & $\begin{array}{l}3 \\
2 \\
5 \\
8 \\
2\end{array}$ & $\begin{array}{r}11 \\
6 \\
14 \\
30 \\
6\end{array}$ & $\begin{array}{l}0.9 \\
1.4 \\
1.4 \\
0.9 \\
1.8\end{array}$ & $\begin{array}{l}0.3-3.8 \\
0.2-9.9 \\
0.4-4.4 \\
0.4-2.1 \\
0.3-10.0\end{array}$ \\
\hline $\begin{array}{l}\text { dockers }(9-7) \\
\text { Transport equipment operators }(9-8) \\
\text { Laborers }^{c}(9-9)\end{array}$ & $\begin{array}{l}7 \\
3 \\
9\end{array}$ & $\begin{array}{l}19 \\
30 \\
32\end{array}$ & $\begin{array}{l}1.7 \\
0.3 \\
1.2\end{array}$ & $\begin{array}{l}0.6-4.6 \\
0.1-1.1 \\
0.5-3.1\end{array}$ \\
\hline
\end{tabular}

a Code of the International Standard Classification of Occupations (7) in parentheses.

b Odds ratio estimated via logistic regression controlling for age, education, area of birth, tobacco smoking, and alcohol drinking.

c Not elsewhere classified.

Table 2 shows corresponding findings for industries (one- or two-digit ISIC codes) and for selected industries including at least two cases and one referent. The building industry; restaurants, bars and hotels; social services; and private services showed a significantly increased risk. A nonsignificant increase in risk $(O R>2.0)$ was found for the textile industry, plastics transformation, tool production, railway equipment production, electricity production, communication industries, and cultural services. The increase in the building industry was due to the high proportion of plumbers and electrical workers; no increase was found when such workers were excluded ( 9 cases, 6 referents).

Selected job titles and industries were further analyzed according to duration of employment. The results of this analysis are shown in table 3. A duration-response effect was suggested for five out of six analyzed jobs, with the exception of printers. On the other hand, out of eight industries, only wood furniture production, foundries, and electrical machinery production had a higher OR with longer duration of employment. A statistically significant trend was shown for plumbers only $(P=0.02)$. Subjects in the categories shown in table 3 were further subdivided according to year of first employment (1945-1955 and 1956 onward). The number of subjects was almost invariably small, and most of them had started their employment during 1945-1955. However, no decline in their risk in recent years was suggested. For example, for an early start of employment, the building workers had an OR of 2.57 ( $1-15$ years) and 2.32 ( $\geq 16$ years); for a late start the OR estimates were 3.14 and 3.71 , respectively.

An additional analysis excluding work history after 1967 was carried out for selected categories in order to take into account a 15-year latency interval, which may be relevant for the etiology of oral cancer. 
Table 2. Odds ratio $(\mathrm{OR})$ and $95 \%$ confidence interval $(95 \% \mathrm{Cl})$ for oral cancer by activity branch and selected industries.

\begin{tabular}{|c|c|c|c|c|}
\hline Activity brancha & $\begin{array}{l}\text { Exposed } \\
\text { cases }\end{array}$ & $\begin{array}{l}\text { Exposed } \\
\text { referents }\end{array}$ & $\mathrm{OR}^{\mathrm{b}}$ & $95 \% \mathrm{Cl}$ \\
\hline Agriculture (1) & 11 & 42 & 0.9 & $0.4-2.7$ \\
\hline $\begin{array}{l}\text { Food industry (31) } \\
\text { Textile, leather and clothing industry (32) }\end{array}$ & $\begin{array}{l}3 \\
6\end{array}$ & $\begin{array}{l}20 \\
22\end{array}$ & $\begin{array}{l}0.5 \\
1.6\end{array}$ & $\begin{array}{l}0.1-1.7 \\
0.5-4.6\end{array}$ \\
\hline $\begin{array}{l}\text { Textile industry }(321) \\
\text { Leather and clothing industries }(322-329)\end{array}$ & $\begin{array}{l}4 \\
2\end{array}$ & $\begin{array}{r}8 \\
14\end{array}$ & $\begin{array}{l}2.5 \\
1.0\end{array}$ & $\begin{array}{l}0.5-9.9 \\
0.2-4.8\end{array}$ \\
\hline Wood industry (33) & 4 & 16 & 0.9 & $0.3-3.0$ \\
\hline Wood furniture industry (332) & 4 & 9 & 1.4 & $0.4-5.5$ \\
\hline Paper industry and printing (34) & 2 & 16 & 0.6 & $0.1-2.9$ \\
\hline Printing and publishing (342) & 2 & 12 & 0.7 & $0.2-3.7$ \\
\hline Chemical, oil, rubber and plastic industry (35) & 10 & 34 & 1.2 & $0.5-2.7$ \\
\hline $\begin{array}{l}\text { Rubber tire industry (3551) } \\
\text { Plastics transformation (356) }\end{array}$ & $\begin{array}{l}4 \\
3\end{array}$ & $\begin{array}{r}17 \\
4\end{array}$ & $\begin{array}{l}1.0 \\
3.5\end{array}$ & $\begin{array}{l}0.3-3.1 \\
0.7-17.6\end{array}$ \\
\hline $\begin{array}{l}\text { Foundries ( } 37 \text { ) } \\
\text { Metal works, machinery production ( } 38 \text { ) }\end{array}$ & $\begin{array}{r}5 \\
38\end{array}$ & $\begin{array}{r}15 \\
164\end{array}$ & $\begin{array}{l}1.0 \\
1.0\end{array}$ & $\begin{array}{l}0.3-3.1 \\
0.6-1.6\end{array}$ \\
\hline Metal works (381) & 7 & 29 & 1.0 & $0.4-2.7$ \\
\hline Tools and related good production (3811) & 2 & 2 & 3.5 & $0.4-29.7$ \\
\hline $\begin{array}{l}\text { Machinery construction ( } 382) \\
\text { Electric machinery }(383)\end{array}$ & $\begin{array}{r}10 \\
3\end{array}$ & $\begin{array}{l}37 \\
19\end{array}$ & $\begin{array}{l}1.1 \\
0.6\end{array}$ & $\begin{array}{l}0.5-2.4 \\
0.2-2.1\end{array}$ \\
\hline Electric machines and material (3831) & 3 & 10 & 0.9 & $0.2-3.6$ \\
\hline Vehicles production $(384)$ & 20 & 104 & 0.7 & $0.4-1.3$ \\
\hline $\begin{array}{l}\text { Railway equipment production (3842) } \\
\text { Car production ( } 3843 \text { ) }\end{array}$ & $\begin{array}{r}3 \\
17\end{array}$ & $\begin{array}{r}2 \\
94\end{array}$ & $\begin{array}{l}7.7 \\
0.7\end{array}$ & $\begin{array}{l}1.0-63.2 \\
0.4-1.2\end{array}$ \\
\hline Gas and electricity production (4) & 4 & 8 & 2.0 & $0.5-7.8$ \\
\hline Electricity production (4101) & 4 & 5 & 2.8 & $0.6-12.1$ \\
\hline Building industry (5) & 29 & 67 & 2.5 & $1.3-4.5$ \\
\hline $\begin{array}{l}\text { Retail sale (62) } \\
\text { Restaurants, bars, hotels (63) }\end{array}$ & $\begin{array}{l}5 \\
6\end{array}$ & $\begin{array}{r}38 \\
4\end{array}$ & $\begin{array}{r}0.4 \\
14.5\end{array}$ & $\begin{array}{l}0.1-1.1 \\
2.8-75.7\end{array}$ \\
\hline Transportation and communication (7) & 8 & 46 & 0.7 & $0.9-1.5$ \\
\hline $\begin{array}{l}\text { Ground transportation }(71,72) \\
\text { Communications }(78)\end{array}$ & $\begin{array}{l}2 \\
3\end{array}$ & $\begin{array}{r}27 \\
7\end{array}$ & $\begin{array}{l}0.3 \\
2.3\end{array}$ & $\begin{array}{l}0.1-1.1 \\
0.5-10.9\end{array}$ \\
\hline Banks and other services to companies (8) & 6 & 40 & 0.8 & $0.3-2.3$ \\
\hline $\begin{array}{l}\text { Public administration and defense (91) } \\
\text { Social services (93) }\end{array}$ & $\begin{array}{r}4 \\
10\end{array}$ & $\begin{array}{l}29 \\
26\end{array}$ & $\begin{array}{l}0.5 \\
2.8\end{array}$ & $\begin{array}{l}0.2-1.6 \\
1.1-6.7\end{array}$ \\
\hline Health services $(9331)$ & 4 & 9 & 2.3 & $0.6-9.1$ \\
\hline Recreational and cultural services (94) & 3 & 5 & 3.3 & $0.6-17.7$ \\
\hline $\begin{array}{l}\text { Repair services (951) } \\
\text { Private services (953) }\end{array}$ & $\begin{array}{l}3 \\
3\end{array}$ & $\begin{array}{r}13 \\
1\end{array}$ & $\begin{array}{r}1.1 \\
34.6\end{array}$ & $\begin{array}{l}0.3-4.7 \\
2.3-524.0\end{array}$ \\
\hline
\end{tabular}

a Code of the International Standard Industrial Classification (8) in parentheses.

b Odds ratio estimated via logistic regression controlling for age, education, area of birth, tobacco smoking, and alcohol drinking.

As compared with values in tables 1 and 2 , the $O R$ was increased for printers (OR 2.6; $95 \%$ CI 0.3-20.6), whereas only minor changes were noticed for the remaining categories.

An analysis of effect modification by tobacco and alcohol was further carried out for all production workers (ILO 7/8/9), electrical workers (ILO 8-51, $8-52,8-53$ ), machinery fitters and assemblers (ILO 8-41, 8-49), plumbers (ILO 8- 71), metal workers (ILO 7-2), and building workers (ISIC 5). The odds ratios were estimated for employment. All the occupational groups showed increasing OR estimates with an increasing amount of smoking, whereas only plumbers showed a similar increase with increased alcohol consumption. The figures in this analysis were very small.

Our series comprised 12 cases of oropharyngeal cancer. No distinct risk pattern emerged from the analy- sis restricted to these men. Specifically, for employment in the textile industry (ISIC 321), the building industry (ISIC 5), car production (ISIC 3843), and the wood furniture industry (ISIC 332) no, three, three, and two cases were reported, respectively.

The results of the analysis based on the application of the job-exposure inatrix are shown in table 4. No OR was statistically different from unity. An association was suggested for formaldehyde exposure (OR 1.6, $95 \% \mathrm{CI} 0.9-2.8$, for any exposure and OR $1.8,95 \%$ CI 0.6-5.5, for probable or definite exposure). When these subjects were analyzed in detail, no consistent dose-response relationship emerged. The exposed cases/referents were $2 / 12$ (category ii), $12 / 43$ (category iii a), $5 / 11$ (category iii b), $3 / 5$ (category iii c), and $3 / 8$ (category iv and v), and the corresponding OR estimates were $0.95,1.71,1.41,2.71$, and 1.22 , respec- 
Table 3. Odds ratio (OR) and $95 \%$ confidence interval $(95 \% \mathrm{Cl})$ for oral cancer by duration of employment in selected occupations and activity branches.

\begin{tabular}{|c|c|c|c|c|c|c|c|c|}
\hline & \multicolumn{4}{|c|}{$1-15$ years } & \multicolumn{4}{|c|}{16 years } \\
\hline & $\begin{array}{c}\text { Exposed } \\
\text { cases }\end{array}$ & $\begin{array}{l}\text { Exposed } \\
\text { referents }\end{array}$ & $\mathrm{OR}^{a}$ & $95 \% \mathrm{Cl}$ & $\begin{array}{c}\text { Exposed } \\
\text { cases }\end{array}$ & $\begin{array}{l}\text { Exposed } \\
\text { referents }\end{array}$ & OR & $95 \% \mathrm{Cl}$ \\
\hline \multicolumn{9}{|l|}{ Occupation' } \\
\hline $\begin{array}{l}\text { Metal workers }(7-2) \\
\text { Machinery workers }(8-41,8-49) \\
\text { Electricians }(8-51,8-52,8-53) \\
\text { Wireman }(8-55) \\
\text { Plumbers }(8-71) \\
\text { Printers }(9-2)\end{array}$ & $\begin{array}{l}2 \\
7 \\
1 \\
1 \\
1 \\
1\end{array}$ & $\begin{array}{r}9 \\
18 \\
5 \\
1 \\
2 \\
4\end{array}$ & $\begin{array}{l}0.8 \\
1.7 \\
0.8 \\
2.9 \\
2.1 \\
1.5\end{array}$ & $\begin{array}{l}0.2-4.1 \\
0.6-4.8 \\
0.1-8.7 \\
0.2-47.9 \\
0.1-32.0 \\
0.1-20.3\end{array}$ & $\begin{array}{l}4 \\
8 \\
3 \\
3 \\
5 \\
1\end{array}$ & $\begin{array}{r}1 \\
15 \\
4 \\
1 \\
3 \\
2\end{array}$ & $\begin{array}{r}12.3 \\
2.2 \\
2.4 \\
5.1 \\
6.4 \\
1.5\end{array}$ & $\begin{array}{l}1.2-123.2 \\
0.8-5.8 \\
0.4-13.2 \\
0.5-53.0 \\
1.2-33.7 \\
0.1-22.6\end{array}$ \\
\hline \multicolumn{9}{|l|}{ Activity branchc } \\
\hline $\begin{array}{l}\text { Wood furniture production (332) } \\
\text { Rubber tire production (3551) } \\
\text { Foundries (371) } \\
\text { Electrical machinery production (3831) } \\
\text { Electricity production (4101) } \\
\text { Building industry (5) } \\
\text { Restaurants, bars, hotels (63) } \\
\text { Health service workers }(9331)\end{array}$ & $\begin{array}{r}1 \\
2 \\
2 \\
1 \\
2 \\
14 \\
4 \\
3\end{array}$ & $\begin{array}{r}6 \\
5 \\
9 \\
5 \\
2 \\
34 \\
2 \\
4\end{array}$ & $\begin{array}{r}0.4 \\
2.6 \\
0.8 \\
0.5 \\
4.3 \\
2.6 \\
21.8 \\
3.8\end{array}$ & $\begin{array}{l}0.0-3.8 \\
0.5-15.0 \\
0.2-3.8 \\
0.1-4.7 \\
0.5-39.8 \\
1.2-5.7 \\
2.3-202.9 \\
0.7-21.8\end{array}$ & $\begin{array}{r}3 \\
2 \\
3 \\
2 \\
2 \\
15 \\
2 \\
1\end{array}$ & $\begin{array}{r}3 \\
12 \\
5 \\
5 \\
3 \\
33 \\
2 \\
5\end{array}$ & $\begin{array}{l}5.5 \\
0.5 \\
1.5 \\
1.4 \\
2.0 \\
2.3 \\
8.5 \\
1.1\end{array}$ & $\begin{array}{l}0.7-44.6 \\
0.1-2.7 \\
0.3-7.7 \\
0.2-8.8 \\
0.3-14.2 \\
1.1-5.0 \\
0.8-97.0 \\
0.1-11.8\end{array}$ \\
\hline
\end{tabular}

a Odds ratio calculated via logistic regression controlling for age, education, area of birth, tobacco smoking, and alcohol drinking.

bode of the International Standard Classification of Occupations (7) in parentheses.

- Code of the International Standard industriat Classification (8) in parentheses.

Based on duration of $1-10$ and $\geq 11$ years.

Table 4. Odds ratio $(O R)$ for oral cancer by occupational exposures determined with an a priori job-exposure matrix.

\begin{tabular}{|c|c|c|c|c|c|c|c|c|}
\hline \multirow{2}{*}{ Chemical } & \multicolumn{2}{|c|}{ Unexposeda } & \multicolumn{3}{|c|}{ Any exposureb } & \multicolumn{3}{|c|}{ Probable or definite exposure } \\
\hline & Cases & Referents & Cases & Referents & $\mathrm{OR}^{\mathrm{d}}$ & Cases & Referents & $\mathrm{OR}^{d}$ \\
\hline Asbestos & 41 & 202 & 45 & 171 & 1.1 & 3 & 28 & 0.4 \\
\hline Polycyclic aromatic hydrocarbons & 30 & 148 & 56 & 225 & 1.0 & 20 & 128 & 0.6 \\
\hline Chromium & 49 & 208 & 37 & 165 & 0.7 & 5 & 16 & 0.9 \\
\hline Nickel & 64 & 256 & 22 & $\uparrow 17$ & 0.8 & - & 3 & 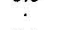 \\
\hline Arsenic & 74 & 317 & 12 & 56 & 0.7 & 2 & 1 & 3.1 \\
\hline Man-made mineral fibers & 65 & 307 & 21 & 66 & 1.5 & 4 & 13 & 1.1 \\
\hline Wood dust & 80 & 333 & 6 & 40 & 0.4 & 6 & 24 & 0.7 \\
\hline Leather dust & 85 & 361 & 1 & 12 & 0.4 & 1 & 5 & 0.9 \\
\hline Isopropyi alcohol & 86 & 364 & - & 9 & $\because$ & - & - & $\because$ \\
\hline Dimethyl sulfate & 86 & 367 & - & 6 & . & - & - & . \\
\hline Naphthalene & 86 & 367 & - & 6 & . & - & - & . \\
\hline Sulfuric acid & 85 & 352 & 1 & 21 & 0.2 & - & 3 & $\cdot$ \\
\hline Formaldehyde & 61 & 294 & 25 & 79 & 1.6 & 6 & 13 & 1.8 \\
\hline Dusts & 36 & 159 & 50 & 214 & 0.8 & 27 & 126 & 0.7 \\
\hline Gases & 35 & 170 & 51 & 203 & 1.0 & 15 & 94 & 0.6 \\
\hline Solvents & 62 & 226 & 24 & 147 & 0.4 & 11 & 59 & 0.6 \\
\hline
\end{tabular}

a Reference category (exposure not higher than for the general population).

b Exposure possibly or definitely higher than for the general population. (See the text for details.)

c Exposure very probably or definitely higher than for the general population. (See the text for details.)

odds ratio estimated via logistic regression, controlling for age, education, area of birth, tobacco smoking, and alcohol drinking. All the $95 \%$ confidence intervals included 1.

tively. Neither were any consistent patterns found for duration of exposure to formaldehyde. Specifically, the OR estimates were 1.7 and 1.5 for $1-15$ years and $\geq 16$ years of exposure, respectively. The corresponding OR estimates for probable or definite exposure were 2.1 and 1.4 , respectively. Finally, the analysis based on job title and industries was repeated after the subjects ever exposed to formaldehyde were excluded in order to evaluate the confounding effect of the latter on the associations shown in tables 1 and 2. Among the categories whose OR was reduced were service workers, electrical workers, printers, painters, and chemical industry workers. For several categories, however, it was impossible to draw any conclusion, given the fact that almost all of the exposed subjects were also classified as exposed to formaldehyde (eg, cabinet makers).

\section{Discussion}

Several occupations and industries were found to be associated with a risk of oral and oropharyngeal cancer in our study, and in other studies as well. The mortality from and incidence of oral or oropharyngeal cancers has been found to be elevated among cooks, waiters, bartenders, and working proprietors (13-18). Many of these studies were based on an analysis of death certificates, and they were unable to control for smoking and alcohol consumption. In our study the risk was confined to working proprietors and cooks, and it remained after control for tobacco smoking and alcohol consumption. Residual confounding due to incomplete adjustment given the small numbers, or a biased report of alcohol or tobacco intake by the cases 
in these categories, might nevertheless explain these results.

Some of the suggested associations with categories of production workers also confirmed the results of previous reports. Oral and pharyngeal cancer risk has been associated with work in the textile and apparel manufacturing industry (19-24), even if other reports $(25,26)$ did not confirm the finding. Machinists and metal working machine operators $(18,27)$, miners $(24)$, workers in the building industry (24), painters (18), plumbers $(27)$, printers $(15,28)$, electronics manufacturing workers $(26,29)$ and electricity production workers (30), and different categories of railway workers $(13,15)$ have previously been suggested to be at increased risk. Performing artists, composers, and art teachers were found to be at higher risk in two studies $(15,16)$. The risk was confirmed in our study for workers in cultural and recreational services, but not for performing artists or workers in the movie, television or theater industry ( 0 cases, 4 referents), as well as for librarians ( 0 cases, 1 referent). The three cases in the cultural and recreational service category were one professional athlete, later a sports coach, one massager and physiotherapist, and one waiter, later manager/ working proprietor of a dance hall.

To avoid potential bias from a differential distribution of risk factors associated with social class $(31,32)$, we controlled our results for educational level. This procedure did not substantially change the OR estimates, a finding suggesting an effect of occupational factors, rather than of variables associated with social class. Standardization for educational level will not control selection bias completely. Nevertheless, when we restricted our analysis to production workers, who are more homogeneous with respect to education, the risk measures did not change with the one exception of the category of miners. The dose-response and latency analysis also add credibility to the major suggestions of our study and increase the consistency between our findings and previous results in the literature. Residual confounding due to alcohol, tobacco, or other life-style factors may still persist in the results, but it is likely to be a major problem only for specific categories such as bartenders and waiters. Alcohol and tobacco consumption did not substantially change the risk estimates in specific occupational groups, when tested (for electrical workers, plumbers, all production workers, metal workers).

In the interpretation of our results obtained with the use of the job-exposure matrix, one must consider that the size of the study was small, with a limited number of subjects definitely exposed to each agent compared with the definitely not exposed. With two exceptions, none of the agents included in the matrix had been previously hypothesized to be related to oral cancer, and the present analysis suggests a lack of any association. The two exceptions are asbestos and formaldehyde. As for the former, one previous study (33) suggested an association, a finding not confirmed in the present study, or in another one (34). Two studies on workers exposed to formaldehyde showed an increased risk of oral cancer $(35,36)$, as did our investigation. Other studies, however, did not support these results $(37,38)$.

Our study was small in size. As a consequence, with few exceptions, it was not possible to control the reciprocal confounding effect of occupational exposures and the interaction between life-style and occupational factors. The possibility of a residual confounding effect by variables included in the analysis, namely, alcohol and tobacco consumption, cannot be ruled out, in particular with respect to categories such as bar and restaurant workers, whose elevated crude risks are expected to be explained by life-style factors rather than by hazards in the workplace. Nevertheless, our study confirmed a number of previously reported occupations and industries at high risk of oral cancer (textile, electrical, and building industries and employment as a machinery operator, plumber, or printer). Finally, the results on formaldehyde exposure, as derived from the application of the job-exposure matrix, are particularly interesting. The use of the job-exposure matrix tends to bias the estimate of risk towards unity, due to an unavoidable misclassification of exposure. Nonetheless, it was the only exposure included in the matrix that showed a dose-response gradient, on the basis of substantial numbers of exposed individuals. Formaldehyde was also, together with asbestos, the only exposure included in the matrix for which there was an a priori hypothesis of an association with oral cancer. Evidence of such an association was strengthened by our results.

\section{Acknowledgments}

This investigation was supported by the Consiglio Nazionale delle Ricerche, Rome (Progetto Finalizzato Oncologia, contracts $85.02391 .44,86.00595 .44$ and 88.00524.44), the Associazione Italiana per la Ricerca sul Cancro, and the Ministry of Public Education. Computer facilities were made available by a grant from Consorzio per il Sistema Informativo, CSI Piemonte, Turin.

The authors acknowledge Dr F Berrino, Dr P Vineis, Dr C Magnani, and Dr G Ciccone for their cooperation and helpful discussions and Ms C Latino, Ms M Nonnato, and Ms A Hanss-Cousseau for their technical help.

\section{References}

1. International Agency for Research on Cancer (IARC). Tobacco smoking. Lyon: IARC, 1986:273-4,309-14. (IARC monographs on the evaluation of the carcinogenic risk of chemicals to humans; vol 38.)

2. International Agency for Research on Cancer (IARC). Alcohol drinking. Lyon: IARC, 1988:165-178,251260 . (IARC monographs on the evaluation of carcino- 
genic risks to humans; vol 44.)

3. Merletti F, Boffetta P, Ciccone G, Mashberg A, Terracini $B$. Role of tobacco and alcoholic beverages in the etiology of cancer of the oral cavity/oropharynx in Torino, Italy. Cancer Res 1989;49:4919-24.

4. Mahoubi E, Sayed GM. Oral cavity and pharynx. In: Shottenfield D, Fraumeni JF, ed. Cancer epidemiology and prevention. Philadelphia, PA: Saunders, 1982: 583-95.

5. Riboli E, Péquignot G, Repetto F, et al. A comparative study of smoking, drinking and dietary habits in population samples in France, Italy, Spain and Switzerland: I. study design and dietary habits. Rev Epidemiol Santé Publique 1988;36:177-85.

6. Tuyns AJ, Estève J, Raymond L, et al. Cancer of the larynx/hypopharynx, tobacco and alcohol. Int J Cancer 1988;41:483-91.

7. International Labour Office. Classification internationale type des professions, Edition révisée. Genève: ILO, 1968.

8. United Nations. Index de la classification internationale type, par industrie, de toutes les branches d'activité économique. New York, NY: United Nations, 1975.

9. Merletti F, Heseltine E, Saracci R, Simonato L, Vainio $\mathrm{H}$, Wilbourn J. Target organs for carcinogenicity of chemicals and industrial exposures in humans: a review of results in the IARC monographs on the evaluation of the carcinogenic risk of chemicals to humans. Cancer Res 1984;44:2244-50.

10. Ferrario F, Continenza D, Pisani P, Magnani C, Merletti F, Berrino F. Description of a job-exposure matrix for sixteen agents which are or may be related to respiratory cancer. In: Hogstedt C, Reuterwall C, ed. Progress in occupational epidemiology. Amsterdam: Elsevier, 1988:379-82.

11. Breslow NE, Day NE. Statistical methods in cancer research; vol 1 (The analysis of case-control studies). Lyon: International Agency for Research on Cancer, 1980; 192-246. (IARC scientific publication; no 32.)

12. Royal Statistical Society. The GLIM system release 3.77 manual. Oxford: Numerical Algorithms Group, 1985.

13. Versluys $\mathrm{JJ}$. Cancer and occupation in the Netherlands. Br J Cancer 1949;3:161-85.

14. Logan WPD. Cancer mortality by occupation and social class, 1851-1971. London: Her Majesty's Stationery Office, 1982 .

15. Dubrow R, Wegman DH. Cancer and occupation in Massachusetts: a death certificate study. Am J Ind Med 1984;6:207-30.

16. Pearce NE, Howard JK. Occupation, social class and male cancer mortality in New Zealand, 1974-78. Int J Epidemiol 1986;15:456-62.

17. Olsen JH, Jensen OM. Occupation and risk of cancer in Denmark: an analysis of 98810 cancer cases, 19701979. Scand J Work Environ Health 1987;13(suppl 1): $1-91$.

18. Vaughan TL. Occupation and squamous cell cancers of the pharynx and sinonasal cavity. Am J Ind Med 1989; 16:493-510.

19. Vogler WR, Lloyd JW, Milmore BK. A retrospective study of etiologic factors in the cancer of the mouth, pharynx, and larynx. Cancer 1962;15:246-58.

20. Moss E, Lee WR. Occurrence of oral and pharyngeal cancers in textile workers. Br J Ind Med 1974;31:224 32.

21. Moss E. Oral and pharyngeal cancer in textile workers. Ann NY Acad Sci 1976;271:301-7.

22. Decouflé P, Stanislawczyk K, Houten L, Bross DJ, Viadana $\mathrm{E}$. A retrospective survey of cancer in relation to occupation. Cincinnati, $\mathrm{OH}$ : National Institute for Occupational Safety and Health, 1977. (NIOSH (DHEW [NIOSH] publication no 77-178.)

23. Blot WJ, Fraumeni JF. Geographic patterns of oral cancer in the United States: etiologic implications. J Chronic Dis 1977;30:745-57.

24. Haguenoer JM, Cordier S, Morel C, Lefebvre JL, Hémon D. Occupational risk factors for upper respiratory tract and upper digestive tract cancers. $\mathrm{Br} \mathrm{J}$ Ind Med 1990;47:380-3.

25. Whitaker CJ, Moss E, Lee WR, Cunliffe S. Oral and pharyngeal cancer in the North-west and West Yorkshire regions of England, and occupation. Br J Ind Med 1979; $36: 292-8$.

26. Winn DM, Blot WJ, Shy CM, Fraumeni JF. Occupation and oral cancer among women in the South. Am J Ind Med 1982;3:161-7.

27. Milham S. Cancer mortality patterns associated with exposure to metals. Ann NY Acad Sci 1976;271:243-9.

28. Lloyd JW, Decouflé P, Salvin LG. Unusual mortality of printing pressmen. J Occup Med 1977;19:543-50.

29. Vagero D, Olin R. Incidence of cancer in electronics industry: using the new Swedish Cancer Environment Registry as a screening instrument. $\mathrm{Br} \mathrm{J}$ Ind Med 1983; 40:188-92.

30. Coggon D, Pannett B, Osmond C, Acheson ED. A survey of cancer and occupation in young and middle aged men: II. non-respiratory cancers. Br J Ind Med 1986; 43:381-6.

31. Fox AJ, Adelstein AM. Occupational mortality: work or way of life? J Epidemiol Community Health 1978; $32: 73-8$

32. Brisson C, Loomis D, Pearce N. Is social class standardization appropriate in occupational studies? J Epidemiol Community Health 1987;41:290-4.

33. Selikoff IJ, Hammond EC, Seidman H. Mortality experience of insulation workers in the United States and Canada, 1943-1976. Ann NY Acad Sci 1979;330:91116.

34. Franco EL, Kowalski LP, Oliveira BV, et al. Risk factors for oral cancer in Brazil: a case-control study. Int J Cancer 1989;43:992-1000.

35. Liebling T, Rosenman KD, Pastides H, Griffith RG, Lemeshow S. Cancer mortality among workers exposed to formaldehyde. Am J Ind Med 1984;5:423-8.

36. Stayner L, Smith AB, Reeve G, et al. Proportionate mortality study of workers in the garment industry exposed to formaldehyde. Am J Ind Med 1985;7:229-40.

37. Acheson ED, Barnes HR, Gardner MJ, Osmond C, Pannett B, Taylor CP. Formaldehyde in the British chemical industry: an occupational cohort study. Lancet 1984; $1: 611-6$

38. Blair A, Stewart P, O'Berg M, et al. Mortality among industrial workers exposed to formaldehyde. J Natl Cancer Inst 1986;76:1071-84.

Received for publication: 24 January 1991 